\title{
Evaluation of pulmonary arterial hypertension: invasive or noninvasive?
}

\author{
A. van der Laarse $\cdot$ P. Steendijk $\cdot$ E. E. van der Wall
}

Received: 3 May 2010/ Accepted: 6 May 2010/Published online: 17 May 2010

(C) The Author(s) 2010. This article is published with open access at Springerlink.com

In medical research animal models have demonstrated their value in elucidating (1) mechanisms of disease, (2) factors implicated in morbidity and mortality of the disease, and (3) new therapeutic avenues to treat the disease. For acute as well as chronic diseases, models for translational medicine have been developed and applied with great benefit. The use of experimental animals should comply with both the Animal Welfare Act and the Guide for the Care and Use of Laboratory Animals in which researchers demonstrate that they have carefully considered the three R's of animal testing alternatives: (1) Reduction of the numbers of animals used, (2) Refinement of techniques and procedures to reduce pain and distress, and (3) Replacement of animals by other models than living animals. Particularly the condition to reduce the number of animals necessary to test a hypothesis is difficult to meet, but the use of animal models and techniques that allow longitudinal measurements from the same animals may lead to a wealth of data from a limited number of animals. In translational research of cardiovascular disease the use of echocardiography allows longitudinal studies of natural history and therapeutic success.

Editorial Comment onto the article of Koskenvuo et al. (doi: 10.1007/s10554-010-9596-1.).

A. van der Laarse · P. Steendijk · E. E. van der Wall ( $\square)$ Department of Cardiology, Leiden University Medical Center, PO Box 9600, 2300 Leiden, The Netherlands e-mail: e.e.van_der_wall@lumc.nl
In the current issue of the International Journal of Cardiovascular Imaging, Koskenvuo and coworkers [1] used echocardiography in a rat model of monocrotaline-induced pulmonary arterial hypertension (PAH). The authors evaluated whether invasive measurements of blood pressures, vascular resistances, right ventricular (RV) wall thickness and RV cavity size could be replaced accurately by corresponding echocardiographic measurements. The authors succeeded to acquire echocardiographic images that produced parameters of PAH with low $(<10 \%)$ intraobserver and low inter-observer variability, except for tissue Doppler derived isovolumetric relaxation time of the RV (IVRT') having an interobserver variability of $22.2 \%$. Regarding diagnostic performance of echocardiographic parameters to detect PAH, i.e. a mean pulmonary arterial pressure $>25 \mathrm{mmHg}$, the authors found a sensitivity of $86.4 \%$, a specificity of $97.6 \%$, a positive predictive value of $92.3 \%$, and a negative predictive value of $93.8 \%$. At day 21, noninvasive assessment of PAH demonstrated large differences between invasively measured systolic PAP and echocardiographically assessed systolic PAP (39.5 \pm 15.5 and $66.4 \pm 18.8 \mathrm{mmHg}$, respectively) and between invasively measured total pulmonary vascular resistance (TPVR) and echocardiographically assessed TPVR $\left(3.5 \pm 2.3\right.$ and $7.7 \pm 2.810^{4} *$ dyn.s.cm $\left.{ }^{-5}\right)$. The authors held these large differences responsible to the absence of significant tricuspid valve regurgitation (TR) jet in several rats with developing PAH. This seems a very likely explanation as at day 35 both 
invasively measured systolic PAP and TPVR approached echocardiographically assessed systolic PAP and TPVR much better. Of note, TPVR has not previously been studied in rodents using echocardiography. It was concluded that the use of non-invasive parameters may replace invasive measurements in detecting successful disease induction and to complement invasive data in the evaluation of PAH severity in a rat model.

The difficulty of performing invasive measurements in animals with advanced PAH is an important limitation of all invasive parameters and underscores the importance of innovative noninvasive measurements. The highly vulnerable status of the RV and more generally of the heart in rats with severe PAH often hampers extensive characterization of $\mathrm{RV}$ function with the pressure-conductance catheter as we have experienced ourselves [2-4]. As a result, echocardiography may have a specific new role in evaluating PAH. The main disadvantage of electrocardiographic assessment of PAH is to accurately assess the functional characteristics of RV. In the present study, in 13 out of $75(17 \%)$ studies no adequate echocardiographic RV measurements could be performed. Generally, assessment of the RV is cumbersome by echocardiography due to limited acoustic window and the abnormal shape of the RV [5-16]. These limitations might be to a certain extent overcome by using transesophageal or 3D-echocardiography [17-21], but magnetic resonance imaging often provides a better visualization of the RV, allowing improved quantification [22-33].

In the current study [1], however, it was clearly shown that employment of echocardiography in animals allows assessment of in vivo RV function without additional harm to the animals. In addition, echocardiography enabled longitudinal measurements thereby lowering the number of animals included in the study. Knowledge and experience in echocardiography of small rodents, so elegantly shown by the authors, is hard to acquire but this is certainly the way to go in future translational research of chronic cardiovascular diseases.

Open Access This article is distributed under the terms of the Creative Commons Attribution Noncommercial License which permits any noncommercial use, distribution, and reproduction in any medium, provided the original author(s) and source are credited.

\section{References}

1. Koskenvuo JW, Mirsky R, Zhang Y et al. (2010) A comparison of echocardiography to invasive measurement in the evaluation of pulmonary arterial hypertension in a rat model. Int J Cardiovasc Imaging. [Epub ahead of print]

2. Hessel MHM, Steendijk P, den Adel B, Schutte CI, van der Laarse A (2006) Characterization of right ventricular function after monocrotaline-induced pulmonary hypertension in the intact rat. Am J Physiol Heart Circ Physiol 291:H2424-H2430

3. Umar S, de Visser YP, Steendijk P et al (2009) Allogenic stem cell therapy improves right ventricular function by improving lung pathology in rats with pulmonary hypertension. Am J Physiol Heart Circ Physiol 297:H1606H1616

4. Steendijk P, Tulner SA, Bax JJ et al (2006) Hemodynamic effects of long-term cardiac resynchronization therapy: analysis by pressure-volume loops. Circulation 113: 1295-1304

5. Tulevski II, Romkes H, Dodge-Khatami A et al (2002) Quantitative assessment of the pressure and volume overloaded right ventricle: imaging is a real challenge. Int $\mathrm{J}$ Cardiovasc Imaging 18:41-51

6. Bleeker GB, Bax JJ, Fung JW et al (2006) Clinical versus echocardiographic parameters to assess response to cardiac resynchronization therapy. Am J Cardiol 97:260-263

7. Bleeker GB, Holman ER, Steendijk P et al (2006) Cardiac resynchronization therapy in patients with a narrow QRS complex. J Am Coll Cardiol 48:2243-2250

8. Ypenburg C, Sieders A, Bleeker GB et al (2007) Myocardial contractile reserve predicts improvement in left ventricular function after cardiac resynchronization therapy. Am Heart J 154:1160-1165

9. Ypenburg C, Schalij MJ, Bleeker GB et al (2007) Impact of viability and scar tissue on response to cardiac resynchronization therapy in ischaemic heart failure patients. Eur Heart J 28:33-41

10. Ypenburg C, van der Wall EE, Schalij MJ, Bax JJ (2008) Imaging in cardiac resynchronisation therapy. Neth Heart $\mathbf{J}$ 16:S36-S40

11. Nemes A, Geleijnse ML, van Geuns RJ et al (2008) Dobutamine stress MRI versus threedimensional contrast echocardiography: it's all black and white. Neth Heart J 16:217-218

12. Hoogsteen J, Hoogeveen A, Schaffers H, Wijn PF, van Hemel NM, van der Wall EE (2004) Myocardial adaptation in different endurance sports: an echocardiographic study. Int J Cardiovasc Imaging 20:19-26

13. Torn M, Bollen WL, van der Meer FJ, van der Wall EE, Rosendaal FR (2005) Risks of oral anticoagulant therapy with increasing age. Arch Intern Med 165:1527-1532

14. van der Wall EE, Heidendal GA, den Hollander W, Westera G, Roos JP (1980) I-123 labeled hexadecenoic acid in comparison with thallium-201 for myocardial imaging in coronary heart disease. A preliminary study. Eur J Nucl Med 5:401-405

15. van der Laarse A, Kerkhof PL, Vermeer F et al (1988) Relation between infarct size and left ventricular performance assessed in patients with first acute myocardial 
infarction randomized to intracoronary thrombolytic therapy or to conventional treatment. Am J Cardiol 61:1-7

16. Bleeker GB, Schalij MJ, Boersma E et al (2007) Relative merits of M-mode echocardiography and tissue Doppler imaging for prediction of response to cardiac resynchronization therapy in patients with heart failure secondary to ischemic or idiopathic dilated cardiomyopathy. Am J Cardiol 99:68-74

17. Bigi R, Desideri A, Cortigiani L, Bax JJ, Celegon L, Fiorentini C (2001) Stress echocardiography for risk stratification of diabetic patients with known or suspected coronary artery disease. Diabetes Care 24:1596-1601

18. Bleeker GB, Steendijk P, Holman ER et al (2006) Assessing right ventricular function: the role of echocardiography and complementary technologies. Heart Suppl 1:i19-i26

19. Tops LF, Schalij MJ, Holman ER, van Erven L, van der Wall EE, Bax JJ (2006) Right ventricular pacing can induce ventricular dyssynchrony in patients with atrial fibrillation after atrioventricular node ablation. J Am Coll Cardiol 48:1642-1648

20. Scherptong RW, Vliegen HW, Winter MM et al (2009) Tricuspid valve surgery in adults with a dysfunctional systemic right ventricle: repair or replace? Circulation 119:1467-1472

21. Kleijn SA, Kamp O (2009) Clinical application of threedimensional echocardiography: past, present and future. Neth Heart J 17:18-24

22. Pluim BM, Beyerbacht HP, Chin JC et al (1997) Comparison of echocardiography with magnetic resonance imaging in the assessment of the athlete's heart. Eur Heart J 18:1505-1513

23. Braun S, van der Wall EE, Emanuelsson S, Kobrin I (1996) Effects of a new calcium antagonist, mibefradil (Ro 405967), on silent ischemia in patients with stable chronic angina pectoris: a multicenter placebo-controlled study. The mibefradil international study group. J Am Coll Cardiol 27:317-322

24. Oosterhof T, Tulevski II, Roest AA et al (2005) Disparity between dobutamine stress and physical exercise magnetic resonance imaging in patients with an intra-atrial correction for transposition of the great arteries. J Cardiovasc Magn Reson 7:383-389
25. de Nooijer R, Verkleij CJ, von der Thüsen JH et al (2006) Lesional overexpression of matrix metalloproteinase-9 promotes intraplaque hemorrhage in advanced lesions but not at earlier stages of atherogenesis. Arterioscler Thromb Vasc Biol 26:340-346

26. Bakx AL, van der Wall EE, Braun S, Emanuelsson H, Bruschke AV, Kobrin I (1995) Effects of the new calcium antagonist mibefradil (Ro 40-5967) on exercise duration in patients with chronic stable angina pectoris: a multicenter, placebo-controlled study. Ro 40-5967 International Study Group. Am Heart J 130:748-757

27. van der Wall EE, den Hollander W, Heidendal GA, Westera G, Majid PA, Roos JP (1981) Dynamic myocardial scintigraphy with 123I-labeled free fatty acids in patients with myocardial infarction. Eur $\mathrm{J}$ Nucl Med 6:383-389

28. Schuijf JD, Bax JJ, van der Wall EE (2007) Anatomical and functional imaging techniques: basically similar or fundamentally different? Neth Heart J 15:43-44

29. Ypenburg C, Roes SD, Bleeker GB et al (2007) Effect of total scar burden on contrast-enhanced magnetic resonance imaging on response to cardiac resynchronization therapy. Am J Cardiol 99:657-660

30. Oemrawsingh PV, Mintz GS, Schalij MJ, Zwinderman AH, Jukema JW, van der Wall EE (2003) Intravascular ultrasound guidance improves angiographic and clinical outcome of stent implantation for long coronary artery stenoses: final results of a randomized comparison with angiographic guidance (TULIP Study). Circulation 107:62-67

31. Posma JL, Blanksma PK, van der Wall EE, Hamer HP, Mooyaart EL, Lie KI (1996) Assessment of quantitative hypertrophy scores in hypertrophic cardiomyopathy: magnetic resonance imaging versus echocardiography. Am Heart J 132:1020-1027

32. Henkens IR, Scherptong RW, van Kralingen KW, Said SA, Vliegen HW (2008) Pulmonary hypertension: the role of the electrocardiogram. Neth Heart J 16:250-254

33. van der Geest RJ, Niezen RA, van der Wall EE, de Roos A, Reiber JH (1998) Automated measurement of volume flow in the ascending aorta using MR velocity maps: evaluation of inter- and intraobserver variability in healthy volunteers. J Comput Assist Tomogr 22:904-911 